\title{
Correlation of clinical features with the risk of lower limb deep vein thrombosis assessed by duplex ultrasound
}

\author{
Correlação de achados clínicos com o risco de trombose venosa \\ profunda de membros inferiores através do ultrassom vascular
}

Liz Andréa Villela Baroncini', Graciliano José França'1, Aguinaldo de Oliveira', Enrique AntonioVidal', Carlos Eduardo Del Valle ${ }^{1}$, Paulo Sérgio Dalla Bona Stahlke ${ }^{1}$, Paulo Henrique Stahlke ${ }^{1}$, Rafael Faucz ${ }^{1}$

\begin{abstract}
Background: Symptoms and clinical signs suggestive of deep vein thrombosis (DVT) are common but may have numerous possible causes. Objectives: 1) To identify the most frequent clinical symptoms and correlate them with duplex ultrasound scan (DS) findings; 2) to identify high-risk clinical conditions for DVT; and 3) to evaluate time since the onset of symptoms and DS examination. Methods: A total of 528 patients with a clinical suspicion of DVT were evaluated by DS performed by experienced vascular ultrasonographists. Results: DVT was present in 192 (36.4\%) of the patients. The external iliac vein was involved in 53 patients (10.04\%), the femoral veins in 110 (20.83\%), the popliteal vein in 124 (23.48\%), and veins below the knee were involved in 157 (29.73\%) of the cases. Limb swelling was present in 359 cases (68\%), and 303 (57.4\%) complained of pain. Sixty nine patients received a DS due to suspected or proven pulmonary embolism (PE); 79 patients were in postoperative period. In the multivariate analysis, independent risk factors for DVT included age $>65$ years $(\mathrm{OR}=1.49 ; 95 \%$ confidence interval [ $95 \% \mathrm{Cl}]$ 1.01-2.18; $\mathrm{p}=0.042)$, edema $(\mathrm{OR}=2.83 ; 95 \% \mathrm{Cl} 1.72-4.65 ; \mathrm{p}<0.001)$, pain $(\mathrm{OR}=1.99 ; 95 \% \mathrm{Cl} 1.3-3.05 ; \mathrm{p}=0.002)$, cancer $(\mathrm{OR}=2.32 ; 95 \% \mathrm{Cl} 1.45-3.72$; $p<0.001)$, and $P E(O R=2.62 ; 95 \% C l$ 1.29-5.32; $p=0.008)$. Time since the onset of symptoms did not differ between the groups. Conclusions: In the present study, $36.4 \%$ of the patients referred to DS had DVT. Age > 65 years, presence of limb swelling, pain, cancer, and suspected or proven PE should be considered as major risk factors for DVT.
\end{abstract}

Keywords: deep venous thrombosis; ultrasonography; edema.

\begin{abstract}
Resumo
Contexto: Sintomas e sinais clínicos indicativos de trombose venosa profunda (TVP) são comuns mas podem ter inúmeras causas. Objetivos: 1) Identificar os sintomas mais frequentes e correlacioná-los com achados de dúplex scan (DS); 2) identificar condições clínicas de alto risco para TVP; e 3) avaliar o intervalo de tempo decorrido entre o início dos sintomas e o exame do paciente. Métodos: Um total de 528 pacientes com suspeita clínica de TVP foram examinadosvia DS por ultrassonografistas vasculares experientes. Resultados: TVP esteve presente em 192 (36,4\%) dos pacientes analisados. A veia ilíaca externa esteve acometida em 53 pacientes (10,04\%), as veias femorais em 110 (20,83\%), a veia poplítea em 124 (23,48\%), e as veias abaixo do joelho em 157 casos (29,73\%). Edema de membro esteve presente em 359 casos (68\%), e 303 (57,4\%) se queixaram de dor. Sessenta e nove pacientes realizaram DS devido a embolia pulmonar (EP) suspeita ou comprovada; 79 pacientes estavam em período pós-operatório. $\mathrm{Na}$ análise multivariada, os fatores de risco independentes para TVP incluíram idade $>65$ anos [OR=1,49; intervalo de confiança de 95\% (IC95\%) 1,01-2,18; $p=0,042]$, edema (OR=2,83; IC95\% 1,72-4,65; $p<0,001)$, dor (OR=1,99; IC95\% 1,3-3,05; $p=0,002)$, câncer ( $O R=2,32 ;$ IC95\% 1,45-3,72; $p<0,001)$ e EP (OR=2,62; IC95\% 1,29-5,32; $p=0,008)$. O tempo decorrido desde o início dos sintomas foi semelhante nos dois grupos. Conclusões: No presente estudo, 36,4\% dos pacientes encaminhados para DS apresentaram TVP. Idade acima de 65 anos, presença de edema de membro, dor, câncer e EP suspeita ou comprovada devem ser considerados fatores de risco maiores para TVP.
\end{abstract}

Palavras-chave: trombose venosa profunda; ultrassonografia; edema.

\footnotetext{
Clínica Áurea, Curitiba, PR, Brazil.

Financial support: None.

Conflicts of interest: No conflicts of interest declared concerning the publication of this article.

Submitted on: 01212013 . Accepted on: 04112013
}

This study was carried out at the vascular ultrasonography units of Clínica Áurea, located in the premises of Hospital Nossa Senhora das Graças and Hospital Pilar (Curitiba, Paraná, Brazil), and also at the vascular ultrasonography service of Hospital de Clínicas da Universidade Federal do Paraná (Curitiba, Paraná, Brazil). 


\section{INTRODUCTION}

Symptoms and clinical signs suggestive of deep vein thrombosis (DVT) are common and have numerous possible causes. A previous studyhas shown that symptoms and clinical signs alone are inaccurate for the diagnosis of $\mathrm{DVT}^{1}$. In clinical practice, physicians see many patients complaining of pain, tenderness, swelling, venous stasis, and/or joint pain in the lower limbs, and it becomes necessary to exclude the diagnosis of DVT. From 60 to $80 \%$ of referred patients do not have DVT, even though they are subjected to diagnostic testing ${ }^{1}$. Some of the clinical conditions that may suggest the presence of DVT include cancer, major orthopedic surgery, abdominal surgery, and other surgical procedures ${ }^{1,2}$.

The objectives of the present study were: 1) to identify the most frequent symptoms and correlate them with duplex ultrasound (DS) findings; 2) to identify high-risk clinical conditions for DVT(primarily age, active cancer, postoperative period of any surgery, and suspected or confirmedpulmonary embolism [PE]) and correlate them with DS results; and 3) to evaluate time since the onset of symptoms and DS examination.

\section{METHODS}

A total of 528 consecutive symptomatic in- and outpatients with a clinical suspicion of DVT (calf or thigh pain, limb swelling, tenderness, cyanosis, cellulitis, venous stasis, and/or joint pain) were evaluated by DS, including the iliac veins. The DS laboratory where images were obtained is located inside a hospital and is available 24 hours a day. Exams were performed on the same day the request was received.

Demographic characteristics and data on risk factors for DVT were collected using a structured questionnaire designed by the investigators according to recommendations from the Non-Invasive Methods Department of the Brazilian Society of Angiology and Vascular Surgery ${ }^{3}$.Data collection also covered clinical symptoms, site of DVT, normal or pathological DS, time (in days)since the onset of symptoms, and associated pathologies, with a focus on active cancer of any kind, postoperative period of any surgery (0 to 30 days after surgery), and confirmed or suspected PE (unexplained and acute dyspnea). PE was confirmed with lung computed tomography (CT)andscintigraphy according to the hospital protocols.

For the final analysis in relation to risk of DVT, subjects were divided into patients with DVT on duplex scan (thrombosis-yes) and absence of DVT on duplex scan (thrombosis-no). Measurements were made using a high-resolution B-mode ultrasound machine (Philips Medical Systems' Envisor C platform) combined with a wide-bandwidth linear array transducer (3-12 MHz). DS exams were performed by three experienced vascular ultrasonographistscertified by the Brazilian Society of Angiology and Vascular Surgery andthe Brazilian College of Radiology.Vein compressibility, presence or absence of venous flow, presence or absence of venous thrombus, and response to the distal compression maneuver were recorded. Interobserver variability was not assessed.

The study was approved by the Research Ethics Committee of the institution of origin.

\section{Statistical analysis}

Categorical variables were expressed as percentages, and continuous variables as means \pm standard deviation (SD). The Student $t$ test or Mann-Whitney's test were used to compare the groups in relation to quantitative variables. Fisher's exact test was used to evaluate the association between qualitative variables and thrombosis. A logistic regression model (backward stepwise) and Wald's test were adjusted to a multivariate analysis to evaluate the relevance of each independent variable on the probability of thrombosis. A ROC curve was calculated to determinethe cutoff point for age and time (in days) since the onset of symptoms and their association with thrombosis. Statistical significance was set at $\mathrm{p}<0.05$. Analyses were performed using the Statisticasoftware version 8.0.

\section{RESULTS}

A total of 528 consecutive symptomatic patients (59.4 \pm 19.5 years, 363 female) were assessed, and DVT was found in $192(36.4 \%$; $95 \%$ CI $32.3-40.5 \%)$. Among patients with DVT, the external iliac vein was involved in 53 patients $(10.04 \%)$, the femoral veins in $110(20.83 \%)$, the popliteal vein in 124 $(23.48 \%)$, and veins below the knee were involved in 157 cases $(29.73 \%)$. The most frequent complaints were swelling (68\%) and/or pain $(57.4 \%)$ in a lower limb. Patients referred to DS without lower limb swelling or pain were inpatients with suspected or proven PE (13.1\%).

Cancer was present in 93 cases (17.8\%). A total of 69 patients (13.1\%) underwent DS due to suspected or proven PE; $79(15 \%)$ where in postoperative period (Table 1).The age of 65 years was established as the cutoff value for the presence of thrombosis, i.e., patients $>65$ years old were found to have a 
greater incidence of DVT when compared to those $<65$ years of age $(\mathrm{p}=0.033)$. Also, DVT was more frequent in patients with limb swelling $(41.78 \%)$ than without swelling $(25.3 \%$; $<<0.001)$ and in patients with cancer $(53.19 \%)$ vs. those without cancer $(32.72 \%$; $<<0.001)$. Sex, pain, postoperative period, $\mathrm{PE}$, and time since the onset of symptoms did not differ between the groups (Table 2).

In the multivariate analysis, independent risk factors for DVT included age, limb swelling, pain, cancer, and PE, i.e., all these variables were found to be major risk factors for the presence of DVT (Table 3). Conversely, there was no cutoff value for time in days since the onset of symptoms that could

Table 1. Patients characteristics and complains

\begin{tabular}{lcc}
\hline \multicolumn{1}{c}{ Variable } & N & $\%$ \\
\hline Age (years; mean \pm SD) & $59.4 \pm 19.5$ & \\
Sex (male/female) & $165 / 363$ & $31.3 / 68.8$ \\
Limb swelling (yes/no) & $359 / 166$ & $68 / 31.4$ \\
Pain (yes/no) & $303 / 221$ & $57.4 / 41.9$ \\
Cancer (yes/no) & $94 / 434$ & $17.8 / 82.2$ \\
Postoperative period (yes/no) & $79 / 449$ & $15 / 85$ \\
Pulmonary embolism (yes/no) & $69 / 459$ & $13.1 / 86.9$ \\
Thrombosis (yes/no) & $192 / 336$ & $36.4 / 63.6$ \\
\hline
\end{tabular}

Table 2. Correlation of the variables assessed with presence or absence of thrombosis.

\begin{tabular}{lccc}
\hline \multicolumn{1}{c}{ Variable } & $\begin{array}{c}\text { Thrombosis- } \\
\text { Yes (\%) }\end{array}$ & $\begin{array}{c}\text { Thrombosis- } \\
\text { No (\%) }\end{array}$ & $\mathrm{p}$ \\
\hline Age & & & \\
$\quad>65$ years & 41.67 & 58.33 & \\
$\quad 365$ years & 32.58 & 67.42 & 0.033 \\
Sex & & & \\
$\quad$ Female & 38.29 & 61.71 & \\
$\quad$ Male & 32.12 & 67.88 & 0.172 \\
Limb swelling & 41.78 & 25.3 & $<0.001$ \\
Pain & 38.94 & 33.48 & 0.200 \\
Cancer & 53.19 & 32.72 & $<0.001$ \\
Postoperative period & 37.97 & 36.08 & 0.747 \\
Pulmonary embolism & 36.23 & 36.38 & 0.981 \\
Time (days; mean \pm SD) & $9.4 \pm 13.7$ & $14.5 \pm 30.5$ & 0.817 \\
\hline SD=standard deviation. & & &
\end{tabular}

Table 3. Major risk factors for thrombosis.

\begin{tabular}{lcrc}
\hline \multicolumn{1}{c}{ Variable } & $\begin{array}{c}\text { Major risk for } \\
\text { thrombosis }\end{array}$ & $\mathrm{p}$ & $\mathrm{OR}(95 \% \mathrm{Cl})$ \\
\hline Age & $>65$ years & 0.042 & $1.49(1.01-2.18)$ \\
Limb swelling & Yes & $<0.001$ & $2.83(1.72-4.65)$ \\
Pain & Yes & 0.002 & $1.99(1.30-3.05)$ \\
Cancer disease & Yes & $<0.001$ & $2.32(1.45-3.72)$ \\
Pulmonary embolism & Yes & 0.008 & $2.62(1.29-5.32)$ \\
\hline
\end{tabular}

$95 \% \mathrm{Cl}=95 \%$ confidence interval; $\mathrm{OR}=$ odds ratio. influence the presence or absence of DVT. Time since the onset of symptoms ranged from $9.4 \pm 13.7$ days in patients with DVT and from $14.5 \pm 30.5$ days in patients without DVT.

\section{DISCUSSION}

Three categories of tests are typically used to determine the probability of DVT: 1) clinical assessment, based on patient history and clinical findings;2) D-dimer assays; and 3) imaging studies, most commonly venous ultrasonography and less commonly $\mathrm{CT}$ scan or magnetic resonance imaging ${ }^{4-6}$. The present study used only venous ultrasonography, also known as DS, to evaluate subjects and correlate results with clinical findings.

D-dimer assays were not available in the present study, asthey are not a routine at the institution. DS, in turn, is considered to be the best noninvasive diagnostic method in symptomatic patients, with an average sensitivity of $97 \%$ for proximal DVT and a mean specificity of $97 \%$; a decreased sensitivity has been reported for calf vein thrombosis ${ }^{7,8}$. DS allows anatomical, morphological, and functional evaluation of the venous system ${ }^{9}$.

Previous studies have reported abnormal DS findings in only $3.6 \%$ of patients without signs or symptoms suggestive of $\mathrm{DVT}^{10}$. In the present study, only patients with signs or symptoms of DVT in the lower limbs or patients with a clinical suspicion of PE were examined. DVT was confirmed by DS in $36.4 \%$ of the cases, demonstrating that symptoms and signs suggestive of DVT are very common and can be caused by other clinical conditions. In other words, DVT does not have unique clinical symptoms;rather, clinical findings are insensitive and nonspecific. In addition, our results showed that several days had elapsed between the onset of symptoms and DS examination.

Additional information regarding the presence or absence of individual risk factors for DVT could considerably improve clinical prediction ${ }^{11}$.In a study by $\mathrm{Kahn}^{1}$, active cancer, paralysis, paresis, a recent lower extremity cast, recent immobilization or surgery, tenderness along the distribution of the deep venous system, swollen thigh and calf (measured), and strong family history of DVT were considered major risk factors. Kan et al. ${ }^{12}$ also reported that a history of thrombophilia was an independent risk factor for DVT.

In the present study, age $>65$ years, presence of limb swelling, pain, cancer, and clinical suspicion of PEwere independent major risk factors for the presence of DVT and should therefore be taken into 
consideration when evaluating a patient forDVT. With regard to patient age, previous studies had already demonstrated that DVT rates increase with age, and that $1 / 100$ of individuals $>70$ years old are affected every year ${ }^{13-15}$.

Limb swelling and pain are very common symptoms, present in many clinical conditions, such as infectious diseases, neoplasia, trauma, inflammatory and vascular conditions, among others ${ }^{14,16}$.In our sample of patients with a clinical suspicion of DVT, limb swelling was the sign/ symptom most commonly observed: $68 \%$ of the patients had this complaint, and DVT was more frequent in these patients. Pain was the second most frequent symptom. Taken together, swelling and pain are significant risk factors for the presence of DVT. With regard to the correlation between cancer and DVT, a study by Kirkova et al. ${ }^{17}$ has reported that advanced cancer patients with bilateral asymmetric lower extremity edema of potentially multifactorial origin have a high incidence of DVT.

In the present study, when patients with a clinical suspicion of PE were analyzed, only $36.23 \%$ showedthrombosis of the lower limbs, which can probably be explained by the fact that not all patients had a confirmed diagnosis of PE. Some patients showed unexplained dyspnea, and PE accounted for only part of the differential diagnosis in these cases. In addition, according to Perrier, DS has a low sensitivity (61\%) for the diagnosis of DVT in patients with $\mathrm{PE}^{18}$,and therefore a negative DS should not rule out $P E^{19,20}$.

Finally, the present study did not find a major incidence of DVT in postoperative patients, despite the frequent presence of pain and swelling in this subpopulation, common symptoms after orthopedic surgery of the lower extremities. In a large series including both postoperative and symptomatic patients, Atri et al. ${ }^{21}$ confirmed that DS is highly accurate for the examination of calf veins.

\section{CONCLUSIONS}

In the present study, $36.4 \%$ of the patients referred to DS actually had DVT. Age $>65$ years old, edema, pain, cancer, and suspected or proven PE should be considered major risk factors for DVT.

\section{REFERENCES}

1. Kahn SR. The clinicaldiagnosis of deepvenousthrombosis. ArchIntern Med. 1998;158:2315-2323. PMid:9827782. http:// dx.doi.org/10.1001/archinte.158.21.2315

2. LópezJA, Kearon C, Lee AYY. Deepvenousthrombosis. Hematology. 2004;439-456. PMid:15561697. http://dx.doi.org/10.1182/ asheducation-2004.1.439
3. Maffei FHA, Caiafa JS, Ramacciotti E, Castro AA. Normas de orientação clínica para prevenção, o diagnóstico e o tratamento da trombose venosa profunda.J Vasc Bras. 2005;4(Supl.3):S205-S220.

4. Bates $S M$, Jaeschke $R$, Stevens $S M$, et al.Diagnosis of DVT. Antithrombotictherapyandprevention of thrombosis, 9th ed: American College of ChestPhysicians. Evidencebasedclinicalpracticeguidelines. Chest. 2012;141(2) (Suppl):e351S-e418S.

5. FraserDGW,Moody AR,Morgan PS, Martel AL, Davidson I.Diagnosis of lower-limbdeepvenousthrombosis: a prospectiveblindedstudy of magneticresonancedirectthrombusimaging. Ann Intern Med. 2002;36:89-98. http://dx.doi. org/10.7326/0003-4819-136-2-200201150-00006

6. Barros MVL, Pereira VSR, Pinto DM. Controversies in thediagnosisandtreatment of deepveinthrombosis for vascular ultrasound. J Vasc Bras. 2012;11:137-143. http://dx.doi. org/10.1590/S1677-54492012000200011

7. PiniM, Marchini L, Giordano A. Diagnosticstrategies in venousthromboembolism. Haematologica. 1999;84:535-540. PMid:10366798.

8. Giannini M, Rollo HA, Maffei FHA. Role of duplex scanning in thediagnosis of asymptomaticlowerextremitydeepvenousthrombosis. J Vasc Br. 2055;4(3):290-6.

9. MantoniM, Larsen L, LundJO, et al.Evaluation of chronicvenousdisease in thelowerlimbs: comparison of fivediagnosticmethods. British J Radiol. 2002;75: 578-583. PMid: 12145130.

10. Marik PE, Andrews L, Maini B. The incidence of deepvenousthrombosis in ICU patients. Chest. 1997;111:661664. PMid:9118705. http://dx.doi.org/10.1378/chest.111.3.661

11. Döffler-Melly J. Diagnosticstrategies in deepvenousthrombosis. Kardiovasculäre Med. 2006;9: 110-115.

12. Kan KK, Koh WP, Chao AKH. Riskfactorsandpresentation of deepvenousthrombosisamongasianpatients: a hospital-basedcase-controlstudy in Singapore. Ann VascSurg. 2007;21:490-495. PMid:17628265. http://dx.doi.org/10.1016/j.avsg.2006.06.008

13. Fowkes FJI, Price JF, Fowkes FGR. Incidence of diagnoseddeepvenousthrombosis in the general population: systematicreview. Eur J VascEndovascSurg. 2003;25:1-5. PMid:12525804. http://dx.doi.org/10.1053/ejvs.2002.1778

14. UsechJN, Castro AMF, Galvis GE, Mantilla RA, Ariza A. Use of US in theevaluation of patientswithsymptoms of deepvenousthrombosis of thelowerextremities. Radiographics. 2008;28:1785-1797. PMid:18936036. http://dx.doi.org/10.1148/ rg.286085513

15. Oliveira A, França GJ, Vidal EA, StalkePSDB, Baroncini LAV. Duplex scan in patientswithclinicalsuspicion of deepvenousthrombosis. CardiovascUltrasound. 2008;6:53. PMid:18937859 PMCid:2576164. http://dx.doi.org/10.1186/1476-7120-6-53

16. Ely JW, Osheroff A, Chambliss L, Ebell MH. Approach toleg edema of unclearetiology. J AmBoardFam Med. 2006;19: 148-160. PMid:16513903. http://dx.doi.org/10.3122/jabfm.19.2.148

17. Kirkova J, Oneschuk D, Hanson J. Deepveinthrombosis (DVT) in advancedcancerpatientswithlowerextremity edema referred for assessment. Am J HospPalliatCare. 2005;22:145-149. PMid:15853094. http://dx.doi.org/10.1177/104990910502200213

18. Perrier A. Noninvasivediagnosis of pulmonaryembolism. Haematologica. 1997;82:328-331. PMid:9234581. 
19. Huisman MV, Klok FA. Diagnostic management of clinicallysuspectedacutepulmonaryembolism. J ThrombHaemost. 2009;7:312-317. PMid:19630824. http://dx.doi. org/10.1111/j.1538-7836.2009.03386.x

20. Schwartz T, Hingorani A, AscherE, et al. Pulmonaryembolismwithoutdeepvenousthrombosis. Ann VascSurg. 2012. Epub, ahead of print.

21. Atri $M$, Herba MJ, Reinhold C, et al.Accuracy of sonography in theevaluation of calfdeepveinthrombosis in bothpostoperativesurveillanceandsymptomaticpatients. AJR. 1996;166:1361-1367. PMid:8633448. http://dx.doi.org/10.2214/ ajr.166.6.8633448
Correspondence Liz Andréa Villela Baroncin Rua Buenos Aires, 764/601 - Bairro Batel CEP 80250-070 - Curitiba (PR), Brazi Fone/Fax: +55 (41)3352-2006 E-mail: lizandreabaroncini@hotmail.com

Author information

LAVB is a PhD, cardiologist physician, echocardiographist, and vascular ultrasonographist, Clínica Cendicardio and Clínica Áurea.

GJF is a PhD, vascular surgeon and ultrasonographist, Sociedade Brasileira de Angiologia e de Cirurgia Vascular (SBACV), Clínica Áurea and Hospital de Clínicas da Universidade Federal do Paraná (UFPR)

$\mathrm{AO}$ is an MSc, vascular surgeon and ultrasonographist, Sociedade Brasileira de Angiologia e de Cirurgia Vascular (SBACV) and Clínica

Áurea.

EAV is an ultrasonographist, Sociedade Brasileira de Angiologia e de Cirurgia Vascular (SBACV), and technical manager, Clínica Áurea.

CEDV is a vascular surgeon and ultrasonographist, Sociedade Brasileira de Angiologia e de Cirurgia Vascular (SBACV) and Clínica

Áurea.

PADBS is a vascular surgeon and ultrasonographist, Sociedade Brasileira de Angiologia e de Cirurgia Vascular (SBACV) and Clínica Áurea.

PHS is a vascular surgeon and ultrasonographist, Sociedade Brasileira de Angiologia e de Cirurgia Vascular (SBACV) and Clínica Áurea. $\mathrm{RF}$ is a radiologist and ultrasonographist, Clínica Áurea.

Author's contributions Conception and design: LAVB, AO, EAV, GJF Analysis and interpretation: $L A V B, G J F$ Data collection: LAVB, AO, EAV, GJF, RF, PSDBS, CEDV, PHS Writing the article: LAVB Critical revision of the article: $L A V B$ Final approval of the article: LAVB, AO, EAV, GJF, RF, PSDBS, CEDV

Statistical analysis: LAVB Overall responsibility: LAVB

"All authors have read and approved of the final version submitted to J Vasc Bras. 